\title{
Distant Teaching and Learning for the Foreseeable Future: Georgian Universities' Students and Professors Perspective
}

\author{
Maia Akhvlediani \\ Akaki Tsereteli State University \\ Sophio Moralishvili \\ Akaki Tsereteli State University \\ Levan Kuprashvili \\ Caucasus University Graduate
}

\begin{abstract}
Like the rest of the world, because of COVID-19 and the new reality, most professors and students suddenly have found themselves forced to use technology while teaching and learning. All of a sudden, every faculty member faced the challenge of delivering education online and accordingly every student receiving education online. On the other hand, it was an overwhelming time for the administration to achieve quality online education at scale. Nevertheless, most universities in Georgia immediately took the challenges of converting to asynchronous learning. The paper presents findings of the survey conducted at the present stage at Georgian private and state universities, comparing students' and professors' satisfaction with elearning. Surprisingly, it appears that professors feel better motivated with online teaching rather than students. Almost every respondent agrees that what seems like the best-case scenario out of this crisis needs much stronger contribution and elaboration in the years ahead.
\end{abstract}

Keywords: pandemics, online learning, students' satisfaction, professors' satisfaction, correlation.

\section{Introduction}

Though we all believe that the face-to-face environment of learning will never go away, it is fascinating how suddenly we woke up in a new really. Moreover, the new reality is that COVID19 is increasingly dominating the way we live, work, study, and rest. If we take even a quick glance at the media, we will be overwhelmed by the predictions of the foreseeable future. What impact can this sharp, forced immersion and experimentation with technology-enabled distance learning have on higher education? What are the feelings of every faculty member who all so suddenly were asked to deliver education online? What are the reactions of every student who unexpectedly started to receive an education online? How happy are they? How satisfied are they? Does it somehow affected their emotional well-being? Finally, what institutions and educators can do to ensure a better rather than worse outcome? As the semester retreats, we think it is high time to ask these questions. 


\section{The Aim of the Study}

The aim of the presented paper is to find out how university professors and students evaluate online teaching and learning experiences, quality of their teaching and learning, engagement during online lectures, satisfaction with assessment methods, and their perspective for the foreseeable future. This will provide educators with useful insight to better plan for the inevitable future.

\section{Students Satisfaction and Online Learning}

Modern technologies have changed the traditional classrooms, the ways professors and students communicate and made it possible to dissolute any type of boundaries. Modern students are inseparable with technologies, they prefer active, rather than passive learning atmosphere, via their gadgets they are part of a highly interactive world, and accordingly, they expect the same in their classes. Therefore, it is obvious that even far ahead of the virus we have been moving slowly towards it. The difference was the fact that some countries have already been well prepared for it others were forced to start it hastily.

Before the pandemics, several studies were conducted regarding students' satisfaction with online learning. At the University of Central Florida, the research aimed to answer the question if there is a possible relationship between student satisfaction with online learning and the theory of psychological contracts. ${ }^{1}$ The authors consider that online learning has separated the classroom and we are no longer bound by physical space. Thus, the solution can be blending.

Gleason, B. \& Greenhow, C. (2017) discuss the Potential of Teaching and Learning via Hybrid Learning in Higher Education. They also suggest that it offers advantages over the traditional classroom, including affordances for fostering students' embodiment in the classroom, their feelings of belonging and trust, and their ability to contribute ideas in authentic ways. Ghilay, Y. (2017) indicates the advantage of integrating technology into learning. Brown, M., Dehoney, J., \& Millichap, N. (2015) in their report outline the key principles to guide the development of a new learning ecosystem. Liu, O. L. (2012) considers critically important to understand student learning and experiences with online education.

Many educators provide survival guides for online teaching and assessment (Boettcher, J., \& Conrad, R. 2010; Clinefelter , David L. 2012; Christopher D. 2014; Johnson, A. 2013; Vai M. \& Sosulski K. 2015)

\section{The Coronavirus Crisis and the World Higher Education}

Hundreds of colleges have announced in early March that because of health concerns related to COVID-19, they are ending in-person classes and moving all instruction to virtual settings. They are using different means around this -some are specifically talking about shifting to online education, while others talk about remote classes and the like. Many of them are taking advantage of (and in some cases extending) spring breaks and other cessations of coursework to prepare for the shift, and it will be some time before they can really tell what forms of learning the institutions will adopt during this period. ${ }^{2}$

\footnotetext{
${ }^{1}$ https://files.eric.ed.gov/fulltext/EJ1062943.pdf

${ }^{2}$ https://www.insidehighered.com/digital-learning/article/2020/03/18/most-teaching-going-remote-will-help-orhurt-online-learning
} 
Different opinions emerged related to distance learning. Will the transition to distance learning be a benefit or detriment to online learning? Some consider that urgent and universal adoption of technology-based learning will support the process of adoption of new forms of learning. Others argue that the transformation done hastily and unprofessionally will be resulted in the flawed product rather than advanced and innovative education.

It has been interesting reviewing about how world-class universities and colleges reacted to the pandemic. Harvard University advised students not to return to campus after spring break and to expect to complete classwork remotely until further notice in an effort to avoid the spread of covid-19. "The idea that Harvard would switch to online classes seemed like an overreaction just a couple of days ago", Jason Furman, professor of the practice of economic policy at the Harvard Kennedy School of Government, wrote in a tweet. ${ }^{1}$

"There will be no face-to-face lectures at the University of Cambridge over the course of the next academic year due to coronavirus" it has been announced. However, lectures will be available to students online and "it may be possible to host smaller teaching groups in person" if they meet social distancing requirements, the university said. University campuses have been closed this term by the Covid-19 outbreak. All teaching at the university was moved online in March, while exams are being carried out virtually. ${ }^{2}$ Protopsaltis, S., \& Baum, S. (2019) state, that technology can not only increase access to education, but as well enhance learning experiences, and reduce the cost of providing high-quality postsecondary education.

As part of \#AtHome campaign, the British Council organised a series of dialogues between universities across Europe and Central Asia. The series aimed to help universities stay connected with their peers from around the world, and share their experience and lessons learned during the Covid-19 crisis. The series explores the challenges many universities face in the areas of distance learning, quality of online classes, student mobility, and research collaboration during the lockdown. This online series brought together Higher Education professionals from around the world. ${ }^{3}$

\section{The Coronavirus Crisis and Higher Education Challenges in Georgia}

To better confront the COVID-19 pandemic an anti-crisis plan was introduced in Georgia. The Minister of Education, Science, Culture, and Sport of Georgia, Mikheil Chkhenkeli urged the professors and the heads of the universities to quickly mobilize resources and switch to distance learning mode to ensure an uninterrupted process of education.

Accordingly, most universities resumed the spring semester from March 16 in the e-learning mode. Since all universities faced one common challenge, all decisions were made based on mutual assistance and the sharing of experiences between state and private universities.

The Minister noted that the universities were advised to follow the guidelines of e-learning and quality assurance developed by the Association of Quality Assurance Agencies of the European Higher Education (ENQA).

At this stage, higher education institutions use various applications and online platforms that promote distance learning such as: Zoom, Microsoft Teams, Moodle, and Google Classroom.

\footnotetext{
${ }^{1}$ https://www.washingtonpost.com/education/2020/03/10/harvard-moves-classes-online-advises-students-stayhome-after-spring-break-response-covid-19/

${ }^{2}$ https://www.bbc.com/news/education-52732814

${ }^{3}$ https://www.britishcouncil.am/en/stay-home/higher-education-dialogue
} 
The Ministry has also developed relevant guidelines and video tutorials for academic staff and students as well. In order to better manage the learning process, the curricula have been modified; online lectures/seminars have been uploaded to the relevant platforms and are now available to all students. Moreover, teaching methods and assessment systems have been revised. The universities have determined the evaluation mechanism based on the recommendation provided by the Ministry. Final exams will be held mainly during stage VI of the restriction relief plan. ${ }^{1}$

Ivane Javakhishvili Tbilisi State University had to introduce a number of changes in the educational process in order to conduct the learning process accordingly. The changes affected the structure of educational programs, teaching methods and the evaluation system. The changes made in each educational programs were different and tailored to the specifics of the program. Teaching at the university using electronic components began on March 16 and all seven faculties gradually introduced the components of e-learning, synchronous and asynchronous. $^{2}$

Kutaisi Akaki Tsereteli State University also accepted the challenge of online teaching and promptly stared using its electronic platforms Microsoft Teams and moodle.atsu.edu.ge. For the implementation of the online training faculties provided professors and students with video guides and tutorials. According to the rector's decree online, blended and hybrid forms were introduced. ${ }^{3}$

Davit Agmashenebeli National Defense Academy of Georgia has also moved to distance learning. In addition, to Zoom's video conferencing app, ILIAS learning platform is used to provide students with multimedia programme and course materials. Things went quite smoothly for both students and professors. As one of the students says, "Because of this format, the same quality and high level of training is provided as during the standard mode". ${ }^{4}$

Caucasus University also carried out the E-Learning process. Lectures have been delivered at the times specified in the university's timetables by means of one of Google's products, namely, the "hangout meet" platform. It took just two or three days to fully implement the new method of online teaching. Transformation was not problematic, primarily because the university has been actively using the online platform with relevant presentations and textbooks. ${ }^{5}$

Gori State Teaching University rector Giorgi Sosiashvili also stated that the university staff and students bravely accepted the challenge: "We were in piloting mode for two weeks, in terms of moving to an online teaching platform. We are currently using the ZOOM app for the learning process, the introduction of which has been supported by the Ministry of Education. Trainings were held for professors and administration, and we began online teaching with students at both undergraduate and graduate levels". ${ }^{6}$

\footnotetext{
${ }^{1} \mathrm{http}: / /$ mes.gov.ge/content.php?id=10329\&lang=eng

${ }^{2}$ https://edu.aris.ge/news/shualeduri-da-finaluri-gamocdebi-ra-cvlilebebs-axorcielebs-tsu-studentebis-shefasebismiznit.html

${ }^{3}$ https://atsu.edu.ge/index.php/en/

${ }^{4}$ https://edu.aris.ge/news/rogor-afaseben-iunkerebi-onlain-swavlebas-da-ras-amboben-erovnuli-tavdacvisakademiis-warmomadgenlebi.html

${ }^{5}$ https://cu.edu.ge/

${ }^{6} \mathrm{https}$ ///edu.aris.ge/news/yvelanair-pirobas-vqmnit-srulyofili-leqciebis-chasatareblad-giorgi-sosiashvili.html
} 
Thus, from the several cases discussed above it is apparent that the majority of universities managed to cope with the unexpected reality quite effectively. Organization for Economic Cooperation and Development (OECD) discharged a report on tackling the educational challenges in 2020 caused by COVID-19 pandemic, which confirms the above mentioned. The study examined practices from 98 countries. According to this report the measures taken by the Georgian government to ensure a continuous education process was viewed as one of the most effective examples. ${ }^{1}$

The OECD recognized Georgia as a leading country in this direction. Anthony Salsito, Vice President of Education at Microsoft Corporation, praised the steps taken by the Ministry of Education, to promote distance learning during the COVID-19 crisis. In his speech, he stated "We are inspired by the tremendous effort and resilience of the Ministry of Education, Science, Culture and Sport of Georgia in responding to the COVID-19 crisis in adapting the system. It was these steps that helped the students, despite the challenges they faced, to continue their studies without any interruption". ${ }^{2}$

\section{Method}

In order to check students' and professors' satisfaction with e-learning we designed a traditional questionnaire, thus we used the quantitative study to gather information. The questionnaire was divided into two parts containing closed-ended questions. The first part contained questions regarding online teaching and learning. The second part provided spaces were professors and students could express freely (the answers were anonymous) their suggestions, recommendations, wishes and solutions. We uploaded the survey questions at google forms and asked professors and students to participate in the survey. Totally, more than 200 people participated in the survey.

The correlation method was chosen to analyze the interconnection and interrelation between two independent surveys, as this method clearly illustrates the relationship between two independent variables. In our survey, two variables were: 1. professors' attitude towards online teaching and 2. students' evaluation of online learning. The conducted analysis gave us the possibility to observe in which questions there was a positive or negative correlation. In addition, it provided us with specific results requiring from the Department further in-depth analysis and solutions.

\section{Survey Results and Analysis}

We present findings of the survey conducted at the present stage at Georgian private and state universities, comparing students' and professors' satisfaction with e-learning. Majority of professors and students were from Akaki Tsreteli State University Pedagogical Faculty, but there were several respondents from Caucasus University and Tbilisi Open University. Overall, our aim was to find out how satisfied professors and students are with online learning process and resources, assessment and interaction.

The first question was related to the possibility of having an appropriate online learning environment, and the necessary technical equipment.

Table 1 Descriptive Statistics for Professor's and Students' Technical Means

\footnotetext{
${ }^{1}$ https://oecdedutoday.com/

${ }^{2}$ http://mes.gov.ge/content.php?id=10318\&lang=eng
} 
Yes

Professors

$93.9 \%$

No

$86.5 \%$

Students
$3 \%$

$8.6 \%$

Other

From the table, it is clear that professors were nonetheless prepared for the process and the preparation week training and consultations appeared to have a positive outcome on the contrary to the students. In their answers students listed reasons like not having appropriate equipment, bad quality or no internet connection, etc.

Table 2

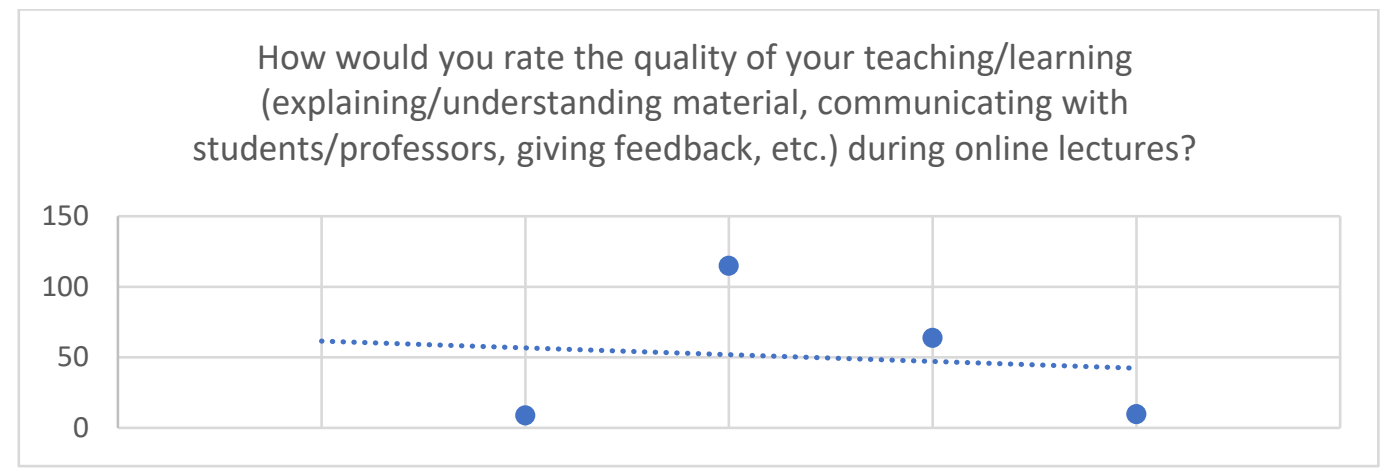

Table 2 presents a general overview of how students and professors generally evaluate the quality of teaching or learning and engagement during online lectures. $27 \%$ of professors rated their quality of teaching as excellent, though none of the students has a similar evaluation. $48 \%$ of students find their online learning satisfactory and $64 \%$ of professors are also content by online teaching. Correlation between students and professors on this question is $76 \%$. This indicated that students and professors are rather satisfied with the quality of online lessons.

Table 3

\section{Teaching/Learning online allows me to better explain/understand the material}

200

0

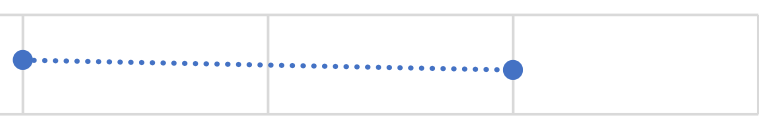

Table 3 presents findings on explaining or understanding the material during online lectures. Professors seem to be more contented by the means they explain the material $(63.6 \%)$ rather than students (53.3\%). However, correlation on this question is $87 \%$. Which proves the fact that both for students and professors the online courses were clear and easily understandable.

Table 4 


\section{Online lectures have given me the opportunity to better assess my teaching/learning methods \\ (explaining/transferring material and understanding/analyzing material)}

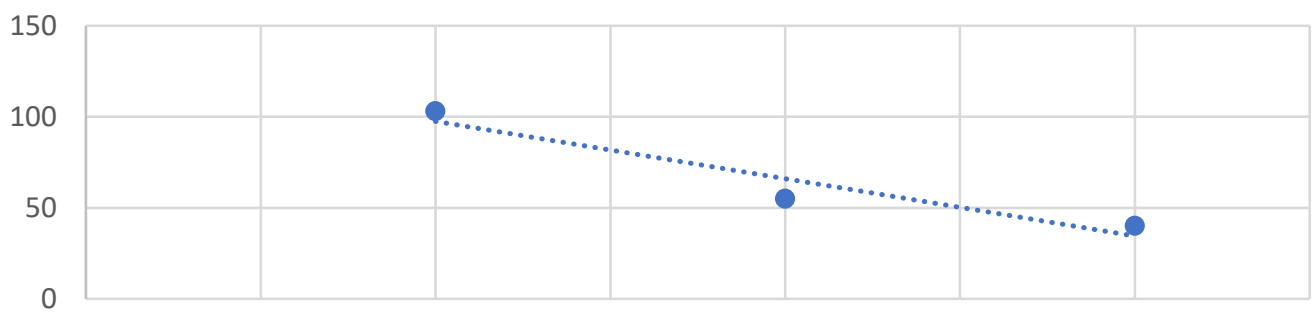

The next question dealt with the very vulnerable issue of self-assessment as online teaching and learning appeared to be a reviler of many drawbacks. The majority of professors (78.8\%) found out that the new way of teaching helped them to better evaluate their teaching methods and abilities. $47 \%$ of students' also found out that online lectures gave to them an opportunity to better evaluate their learning possibilities, but still, there is $23 \%$ who gave negative answer. Correlation between students and professors on this question is rather high - 78\%. A high percentage of correlation underlines that most of the students and professors gave positive answers to the upper mentioned question, which means positive feedback in terms of evaluating the participant itself.

Table 5

\section{During online lectures, professors/students are given the opportunity to ask questions (express opinion, etc.) and receive feedback from professors}

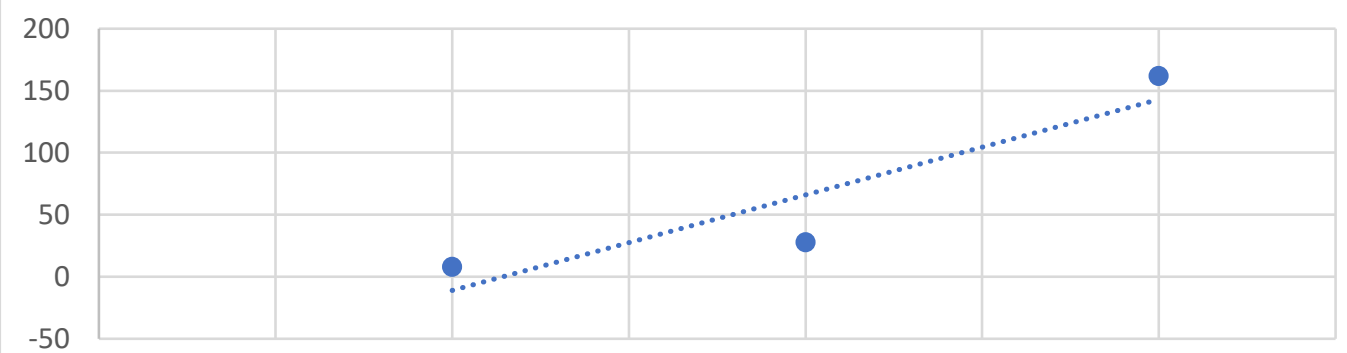

Table 5 presents findings of the opportunity of interaction, which appeared to be very crucial during the pandemics as we were deprived of the possibility of face-to-face communication. Thus, our intention was to find out not only the quality of delivering or attending lectures but also how professors and students cope with the problem of online communication. Correlation between students and professors on this question is 71\%. Professors' answers (93.9\%) imply that they always gave chances to students to express themselves freely and the majority of students agreed (79.4\%). This strongly proves that students nearly always had the opportunity to ask questions during the sessions and receive feedback. 
Table 6

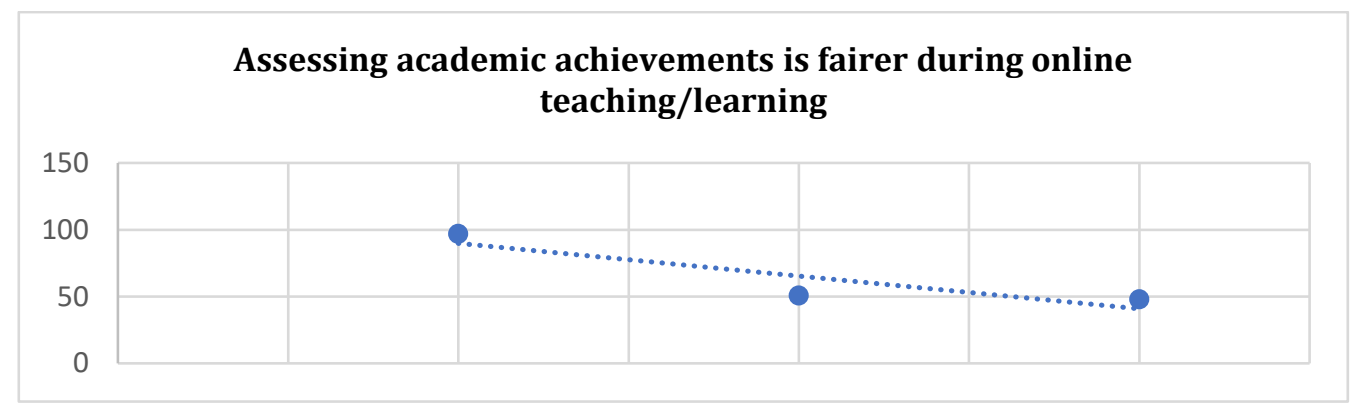

It appears that neither professors nor students have a clear idea weather assessing academic achievement is fairer during online teaching/learning or not. Only $27.3 \%$ of professors said yes, and $33.3 \%$ found it difficult to give an answer. $51.5 \%$ of students were also uncertain about the answer, 24\% said "yeas" and 25\% said "no". Correlation between students and professors on this question is $88 \%$. Together these results strongly indicated that both students and professors were unable to give the definite answer to the issue related to the assessment.

Table 7

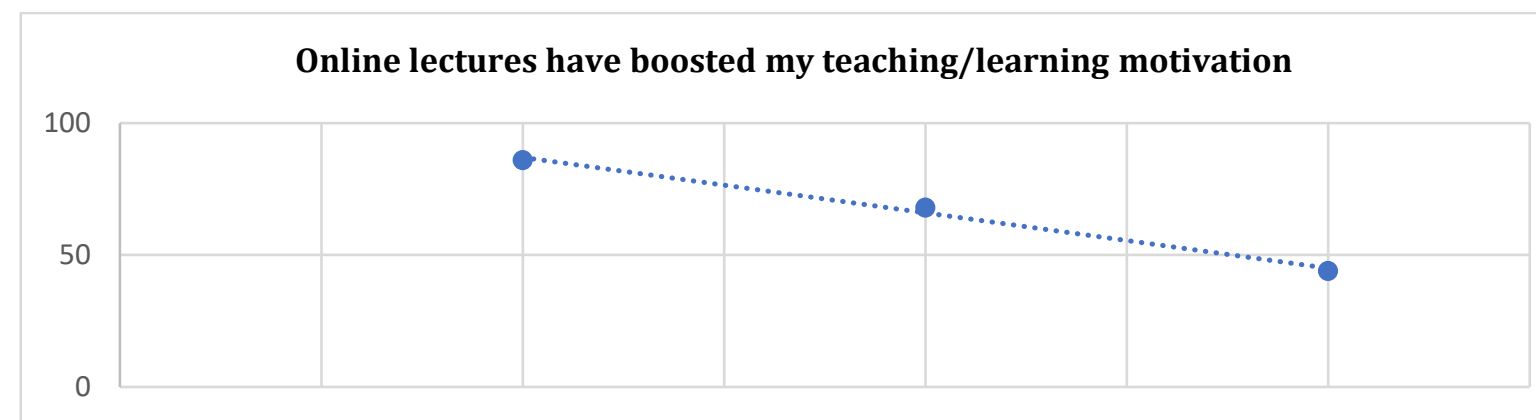

Surprisingly, it appears that professors feel better motivated with online teaching $69.7 \%$ rather than students $38.2 \%$. Students pointed out that they miss a lot of their university classes and professors though they also stated that professors made a good effort to explain the material clearly and thoroughly. Students also accentuated the fact that in this way their responsibility and self-drive increased immensely as they felt motivated and even more obliged to learn. They also found that this type of learning was more convenient for them. For professors, it was an extra motivation to prepare online causes and experiment with innovative methods.

Correlation between students and professors on this question is $61 \%$. The answers strongly indicated that professors were more motivated with the online courses rather than students. In addition, nearly a quarter of the students hesitated to give the answer. This indicator may be crucial to investigate why the younger generation was not happy about online courses.

To sum up, major problems encountered during online teaching and learning from professors and students perspective were 1 . The internet connection (some students are from remote places, but sometimes the problem was thought out); 2 . Technology literacy (some professors 
say that teaching online is harder and requires additional skills); 3 . Remote assessment (some still argue that it is acceptable in terms of formative assessment, but not for summative); 4 . Students' motivation.

\section{Conclusions}

We may conclude that currently, all educational institutions face the same challenges even though they might have found different solutions. For students and professors, as the major actors of the education process, this is the most challenging time since the format, mode, and the shape of the teaching and learning process affect them. How shall we prepare for the foreseeable future? A lot will depend on the instructors' competencies to be able to build the balance by providing opportunities for students to learn in an informal atmosphere. With good instructions professors can turn their students into self-determined learners, technologybased pedagogy can help to solve some of the problems.

Currently, we need some guidelines from the government of Georgia introduced in the Law on Higher Education to decide which form is more acceptable fully online or blended, synchronous or asynchronous, how to assure quality, how to control, how to assess, how to modify curriculum and teaching methods etc. There are a number of questions at a present stage, which are remaining unanswered and need further research and investigation. However, one thing is clear, whatever the perspective is for the foreseeable future we need to enhance methods and innovate learning systems.

\section{References}

[1] Boettcher, J., \& Conrad, R. (2010). The online teaching survival guide: Simple and practical pedagogical tips. San Francisco: Jossey-Bass.

[2] Brown, M., Dehoney, J., \& Millichap, N. (2015). The next generation digital learning environment. Retrieved April 28, 2020, from Educause Learning Initiative: https://library.educause.edu/ /media/files/library/2015/4/eli3035-pdf.pdf

[3] Clinefelter , David L. (2012). Best Practices in Online Faculty Development. Louisville, KY: The Learning House, Inc.

[4] Christopher D. (2014) The Successful Virtual Classroom: How to Design and Facilitate Interactive and Engaging Live Online Learning, New York.

[5] Kathryn E. Linder and Chrysanthemum Mattison Hayes ; foreword by Kelvin Thompson.High-impact practices in online education : research and best practices, First edition, Sterling, Virginia : Stylus Publishing, 2018.

[6] Ghilay, Y. (2017). Online learning in higher education. New York, NY: Nova Science Publishers.

[7] Gleason, B. \& Greenhow, C. (2017). Hybrid learning in higher education: The potential of teaching and learning with robot-mediated communication. Online Learning, 21(4), 159-176. doi: 10.24059/olj.v21i4.1276

[8] Johnson, A. (2013) Excellent Online Teaching: Effective Strategies for A Successful Semester Online, First Edition.

[9] Linder, Kathryn E.(2017) The blended course design workbook : a practical guide, Sterling, Virginia : Stylus Publishing, LLC, 2017.

[10] Liu, O. L. 2012. Student evaluation of instruction: In the new paradigm of distance education. Research in Higher Education 53 (4): 471-486. 
[11] Lowenthal, P. R., Bauer, C., \& Chen, K-Z. (2015). Student perceptions of online learning: An analysis of online course evaluations. American Journal of Distance Education.

[12] Protopsaltis, S., \& Baum, S. (2019). Does Online Education Live Up to Its Promise? A Look at the Evidence and Implications for Federal Policy.

[13] Vai M. Sosulski K. (2015) Essentials of Online Course Design, second edition.

[14] Velez-Solic A. (2015) Teaching Online Without Losing Your Mind: A Comprehensive Overview, AVS Academic Services.

[15] https://worldwidescience.org/topicpages/s/student+satisfaction+scores.html

[16] https://www.zdnet.com/article/online-learning-gets-its-moment-due-to-covid-19pandemic-heres-how-education-will-change/

[17] https://www.insidehighered.com/digital-learning/article/2020/03/18/mostteaching-going-remote-will-help-or-hurt-online-learning 